\title{
CHALLENGES AND NEW METHODS IN THE DIAGNOSIS OF LYME DISEASE IN CHILDREN
}

\section{WYZWANIA I NOWE MOŻLIWOŚCI W DIAGNOSTYCE BORELIOZY U DZIECI}

\author{
${ }^{1}$ Medical University of Bialystok, Department of Pediatric Infectious Diseases \\ Uniwersytet Medyczny w Białymstoku, Klinika Obserwacyjno-Zakaźna Dzieci
}

\begin{abstract}
Despite the constant development of biotechnology, laboratory diagnostics of Lyme disease in children still poses a significant challenge. The aim of this article is to present the current methods of Lyme disease diagnosis and its future perspectives.

A serological test is often the first step in supporting clinical diagnosis of Lyme disease in children. Recently, a new generation of enzyme-linked immunosorbent assays has been created. These assays use recombinant proteins or synthetic peptides in their antigenic spectrum. It is postulated that these tests may replace the classic immunoblot as the second step in the Lyme disease diagnostic protocol. Direct detection methods based on bacterial culture techniques or using the polymerase chain reaction (PCR) have inadequate sensitivity, which prevents their widespread use in clinical practice. Recently, a number of other tools have been developed that are of supportive importance. Among them, measuring of the CXCL13 chemokine concentration in the cerebrospinal fluid has the potential to become a routine procedure in the diagnosis of Lyme disease in children.

Future diagnostic strategies of Lyme disease might include: innovative immunological tests using new antigens, combining serology with direct methods in order to increase sensitivity, standardization of selected unconventional tests, identification of host response biochemical metabolic markers or linking clinical symptoms reported by patients with appropriate test panels.

In the absence a vaccine which protects against the disease, the preventive recommendations given to parents to prevent tick bites in children remain valid.
\end{abstract}

Keywords: Lyme disease, diagnosis, symptoms, serology, unconventional tests

\section{STRESZCZENIE}

Pomimo ciągłego rozwoju biotechnologii, diagnostyka laboratoryjna boreliozy u dzieci pozostaje nadal niemałym wyzwaniem. Celem tej pracy jest przedstawienie obecnych możliwości diagnostycznych choroby z Lyme oraz perspektyw na nadchodzącą przyszłość.

Badanie serologiczne jest często pierwszym krokiem wspierającym diagnostykę kliniczną u dziecka chorego na boreliozę. W ostatnim czasie pojawiły się testy immunoenzymatyczne nowej generacji, które wykorzystują w swoim spektrum antygenowym rekombinowane białka lub syntetyczne peptydy. Postuluje się, iż testy te mogą zastąpić klasyczny immunoblot, jako drugi etap protokołu diagnostycznego boreliozy. Diagnostyka bezpośrednia oparta na technikach hodowli bakterii lub wykorzystująca reakcję łańcuchową polimerazy (PCR) charakteryzuje się nadal nieadekwatną czułością, co uniemożliwia jej powszechne zastosowanie w praktyce klinicznej. W ostatnim czasie opracowano szereg innych narzędzi, które mają znaczenie pomocnicze. Wśród nich pomiar stężenia chemokiny CXCL13 w płynie mózgowo-rdzeniowym wydaje się być bliski rutynowego zastosowania u dzieci z neuroboreliozą.

Przyszłe strategie diagnostyczne boreliozy mogą polegać na: zastosowaniu nowatorskich testów immunologicznych wykorzystujących nowe antygeny, połączeniu serologii z metodami bezpośrednimi w celu poprawy czułości, standaryzacji niektórych niekonwencjonalnych testów, identyfikacji biochemicznych markerów meta-

(C) National Institute of Public Health - National Institute of Hygiene / Narodowy Instytut Zdrowia Publicznego - Państwowy Zakład Higieny 
bolicznych odpowiedzi gospodarza na zakażenie, czy też na odkryciu powiązań zgłaszanych przez pacjentów objawów klinicznych choroby z odpowiednimi panelami diagnostycznymi.

Wobec braku dostępnej szczepionki chroniącej przed zachorowaniem wciąż aktualne pozostają zalecenia profilaktyczne przekazywane rodzicom dzieci, które mają zapobiegać podkłuciom przez kleszcze.

Słowa kluczowe: borelioza, diagnostyka, objawy, serologia, testy niekonwencjonalne

\section{INTRODUCTION}

Lyme disease, also known as Lyme borreliosis, is a multi-organ bacterial disease that is transmitted through a tick bite. Its symptoms mainly affect the skin, joints, heart and nervous system. In the 1970s, in Old Lyme, Connecticut, USA, a series of cases of arthritis in children was reported. The symptoms were associated with the bites of ticks (1). It took many years to discover the cause of the disease - the bacteria named after its discoverer Borrelia burgdorferi (2). Identification of the etiological factor was certainly a milestone in understanding the etiopathology of the disease. However it did not become a remedy for diagnostic and therapeutic problems. Unfortunately, the diagnosis of Lyme disease still presents a significant challenge, despite the biotechnological breakthrough that has undoubtedly occurred in recent years. The techniques that directly detect the diseasecausing microorganisms are the gold standard in the diagnosis of many infectious diseases, against which other diagnostic methods are compared. One of these techniques is molecular testing, which is a diagnostic tool in many diseases, including the recently recognized Zika virus infections or SARS-CoV-2.

\section{DIRECT DIAGNOSTICS}

Culture methods are useful tools for diagnosing infectious bacterial diseases. However, this does not apply to Lyme disease. Despite many attempts, the required sensitivity of these methods was not achieved. In a well-defined group of patients, the improved method of sampling together with the optimization of the medium composition gives positive culture results in only $47 \%$ of cases on the sixth day after the blood culture. This percentage does not increase to $94 \%$ until 16 weeks after the culture (3). These results come far too late for blood cultures to be of clinical significance. The culture method used in the case of skin biopsies collected from the area of erythema migrans, an early symptom of Lyme disease, has a sensitivity of only $50 \%$ (4-5). Moreover, this method is of limited use in children due to its invasiveness. Therefore, culture is not a routine procedure applicable in everyday clinical practice in the diagnosis of Lyme disease. This method is characterized by relatively low sensitivity. In addition, it requires a lot of time to obtain results

\section{WSTEP}

Borelioza, znana także jako choroba z Lyme, jest wielonarządową chorobą bakteryjną przenoszoną przez ukłucie kleszcza. Jej objawy dotyczą przede wszystkim skóry, stawów, serca i układu nerwowego.

W latach siedemdziesiątych XX wieku w mieście Old Lyme w stanie Connecticut w USA opisano serię przypadków zapalenia stawów u dzieci. Objawy powiązano z ukłuciami kleszczy (1). Minęło wiele lat zanim ostatecznie rozpoznano przyczynę choroby - bakterię nazwaną później od nazwiska odkrywcy Borrelia burgdorferi. (2). Zidentyfikowanie czynnika etiologicznego było z pewnością kamieniem milowym w zrozumieniu etiopatologii choroby, jednak nie stało się remedium na istotne dla pacjentów problemy diagnostyczne i terapeutyczne. Wydaje się, że od czasu opisania nowej choroby w miejscowości Old Lyme po dzień dzisiejszy, rozpoznanie boreliozy stanowi istotne wyzwanie, pomimo przełomu biotechnologicznego, który bezsprzecznie nastąpił w ostatnich latach. W diagnostyce wielu chorób zakaźnych złotym standardem, do którego porównuje się inne metody diagnostyczne, są techniki umożliwiające bezpośrednie wykrywanie mikroorganizmów odpowiedzialnych za wywoływanie choroby. Jedną z takich technik jest badanie molekularne, które obecnie stanowi narzędzie diagnostyczne wielu chorób, w tym niedawno poznanych zakażeń wirusem Zika, bądź SARS-CoV-2.

\section{DIAGNOSTYKA BEZPOŚREDNIA}

Metody hodowlane są użytecznym narzędziem stosowanym $\mathrm{w}$ diagnozowaniu bakteryjnych chorób zakaźnych. Nie dotyczy to jednak boreliozy. Pomimo wielu prób nie udało się uzyskać wysokiej czułości tej metody. W dobrze zdefiniowanej grupie chorych ulepszony sposób pobierania próbek wraz z optymalizacją składu pożywki daje pozytywne wyniki hodowli jedynie w $47 \%$ przypadków w szóstym dniu od posiewu krwi. Odsetek ten wzrasta do $94 \%$ dopiero w 16 tygodniu od wykonania posiewu (3). Jest to zdecydowanie za późno, by posiewy krwi miały istotne znaczenie kliniczne. Metoda hodowlana zastosowana w przypadku bioptatów skóry pobranych z okolicy rumienia wędrującego, wczesnego objawu boreliozy, charakteryzuje się czułością na poziomie zaledwie 50\% (45). Ponadto metoda ta ma ograniczone zastosowanie 
and an above-average proficiency in the use of modern techniques.

Histopathology is a method that could help observe the pathogen or the characteristic cell infiltration that could lead to the correct diagnosis. In case of Lyme disease, histopahtology is recommended when lymphocytoma and acrodermatitis chronica atrophicans are suspected (6). Both of the above mentioned are extremely rare in children, therefore histopathological examination is not applicable to the most common forms of the disease in this age group.

Low amount of circulating Borrelia burgdorferi DNA is the reason why molecular techniques do not provide promising results in the early stage of the disease. It is estimated that the sensitivity of the PCR (polymerase chain reaction) method is comparable to the sensitivity of in vitro culture: it is calculated/ evaluated ?? at $62 \%$ (7) in early Lyme disease, $38 \%$ in acute Lyme neuroborreliosis and $25 \%$ in chronic Lyme neuroborreliosis (8).

The unsatisfactory sensitivity of direct diagnostic methods can be improved by applying several such methods simultaneously. One of the studies (9) assessed the sensitivity of five direct diagnostic methods. At least one of these tests was positive in nearly $94 \%$ of untreated adults with erythema migrans. This study did not include a control group and because of this reason the specificity of the diagnostic approach using these methods could not be established. Detection of cell-free DNA fragments of Borrelia burgdorferii (cfDNA) in plasma may become another new approach supporting the diagnosis of Lyme disease in the early stages of the disease. A positive result was obtained in $64 \%$ of the samples from patients with confirmed erythema migrans. The combination of cfDNA determination with serology increased the diagnostic sensitivity to a promising $86 \%$ (10). Taking into account the fact that the detection of Borrelia burgdorferi using direct methods is of limited use, it should be considered whether relying only on commonly employed serological tests provides sufficient support for the clinical diagnosis of Lyme disease.

\section{SEROLOGICAL DIAGNOSTICS}

The Conventional Two-Tiered Testing (CTTT) of Lyme disease includes a first-tier enzyme immunoassay (EIA) followed by a supplemental immunoblot. This method is the most common tool supporting the clinical diagnosis of Lyme disease. There are studies that estimate the sensitivity of the two-stage diagnostic protocol reaches unrealistic 100\% in the late stages of the disease (11), while other studies suggest $56 \%$ (12) or less (13). The fact that the tests are not fully standardized and the stages of the disease are u dzieci z uwagi na jej inwazyjność. Hodowla nie jest więc rutynową procedurą mającą zastosowanie w codziennej praktyce klinicznej w przypadku podejrzenia boreliozy. Cechuje ją stosunkowo niska czułość, długi czas potrzebny do uzyskania wyników oraz wymaga ponadprzeciętnej biegłości w stosowaniu nowoczesnych technik przez personel laboratorium.

Histopatologia to kolejna bezpośrednia technika, która mogłaby pomóc w uwidocznieniu patogenu lub wykazać obecność charakterystycznego nacieku komórkowego pomocnego $\mathrm{w}$ ustaleniu prawidłowego rozpoznania. Technika ta w przypadku boreliozy zalecana jest tylko w ocenie przypadków podejrzanych o chłoniaka boreliozowego lub przewlekłe zanikowe zapalenie skóry (6). Obie postaci są niezwykle rzadko spotykane u dzieci, tym samym badanie histopatologiczne nie ma zastosowania w najczęściej spotykanych postaciach choroby w tej grupie wiekowej.

Mała ilość krążącego DNA Borrelia burgdorferi jest powodem, dla którego nie widzimy obiecujących wyników stosowania technik molekularnych we wczesnym stadium choroby. Ocenia się, iż czułość metody PCR (ang. polymerase chain reaction) jest porównywalna $\mathrm{z}$ czułością hodowli in vitro: szacuje się ją na $62 \%$ (7) we wczesnym stadium boreliozy, $38 \% \mathrm{w}$ ostrej neuroboreliozie i na $25 \%$ w przewlekłej neuroboreliozie (8).

Niezadowalająca czułość bezpośrednich metod diagnostycznych może być poprawiona poprzez zastosowanie kilku takich metod jednoczasowo. Jedno z badań (9) oceniało pięć bezpośrednich metod diagnostycznych pod kątem czułości. Co najmniej jeden z tych testów był dodatni u niemal $94 \%$ pacjentów, $\mathrm{w}$ grupie nieleczonych dorosłych $\mathrm{z}$ rumieniem wędrującym. Badanie to było pozbawione próby kontrolnej, co nie pozwoliło na ustalenie swoistości podejścia diagnostycznego z wykorzystaniem tych metod. Wykrywanie wolno krążących w osoczu fragmentów DNA Borrelia burgdorferii (cfDNA) może stać się kolejnym nowym podejściem wspierającym diagnostykę boreliozy we wczesnym stadium choroby. Pozytywny wynik uzyskano w $64 \%$ próbek pochodzących od pacjentów z potwierdzonym rumieniem wędrującym. Połączenie oznaczania cfDNA z serologią zwiększyło czułość diagnostyczną do obiecujących $86 \%$ (10). Biorąc pod uwagę fakt, iż wykrywanie Borrelia burgdorferi metodami bezpośrednimi ma ograniczone zastosowanie, należałoby zastanowić się, czy poleganie jedynie na stosowanych powszechnie badaniach serologicznych może być obecnie wystarczającym wsparciem klinicznego rozpoznania boreliozy?

\section{DIAGNOSTYKA SEROLOGICZNA}

Klasyczna dwuetapowa strategia diagnostyki laboratoryjnej boreliozy (ang. CTTT: Conventional Two 
not clearly defined, as well as the retrospective nature of many scientific studies, make it even more difficult to determine the actual sensitivity of the diagnostic technique used. As the infection with Borrelia burgdorferi progresses from early to late stage, an increase in the sensitivity of the test is observed. CTTT used in the late stages of Lyme disease shows high sensitivity. However, the late stages of the disease are rarely observed in pediatric patients. Serological tests are useless in the very early stages of the infection as it takes time to detect the body's antibody response. Diagnostic tests performed too early result in false-negative results, found in $70 \%$ of patients in the early stages of the disease (11). The immunoblot confirmation test is time-consuming, expensive, and characterized by lower sensitivity compared to EIA. However, it's specificity is significantly higher than that of EIA. The immunoblot test may give a false negative result in the first weeks of infection. If the obtained result is questionable, a second test is required. IgM immunoblot is recommended only for the diagnosis of the early stage of the disease (up to 4 weeks) and should not be used in later diagnosis. Incorrect use of this technique in patients with prolonged, nonspecific symptoms may give a false positive result rather than an indication of an actual infection (14).

The Modified Two-Tiered Testing (MTTT) relies on two different sequential EIAs without the inclusion of an immunoblot (15). Serological tests using bacterial whole cell lysate as antigen are very sensitive, but may cross-react with other epitopes. A new type of EIA was developed that used recombinant proteins or synthetic peptides unique to Borrelia burgdorferi. Serological tests based on such epitopes may be useful as a second test in the MTTT. This is possible due to the minimal cross-reactivity of the new EIA test with foreign antigens. The antigen used in the new generation enzyme immunoassays is surface lipoprotein E (VlsE) or a selected part of it, most often the C6 peptide epitope corresponding to the sixth invariant region (IR6) in VlsE (16). In vivo highly expressed antigens in VlsE can significantly improve the sensitivity of the test (17-19). The use of the C6 peptide derived from VIsE in the antigenic spectrum improves the specificity of the test compared to the EIA whole cell lysate $(17,20)$. Tests using the additional VlsE antigen could eventually replace immunoblotting as a confirmation test for Lyme disease. This strategy allowed the correct identification of patients with septic arthritis in a large group of children with symptoms of arthritis (21). The test has also been successfully used to evaluate the effectiveness of Lyme disease treatment (22-23), although repeating antibody-based testing is not routinely recommended in clinical practice.
-Tiered Testing), definiowana jest jako zastosowanie czułego testu immunoenzymatyczny (EIA), po którym wykorzystujemy uzupełniające wysoko swoiste badanie immunoblot. Ten scenariusz pozostaje najpowszechniej stosowanym narzędziem wspierającym diagnostykę kliniczną boreliozy. Istnieją badania, które szacują czułość dwuetapowego protokołu diagnostycznego w późniejszych manifestacjach choroby na nierealistyczne $100 \%(11)$, podczas gdy inni podają czułość na poziomie 56\% (12) lub mniej (13). Brak pełnej standaryzacji testów, jak również brak jasnej definicji etapów choroby oraz retrospektywny charakter wielu opracowań naukowych sprawiają, że ustalenie faktycznej czułości zastosowanej techniki diagnostycznej staje się jeszcze trudniejsze. Wraz z progresją zakażenia Borrelia burgdorferi, od stadium wczesnego do późnego, obserwujemy wzrost czułości testu. Zastosowanie CTTT w później boreliozie odznacza się bardzo wysoką czułością. Jednak w grupie pacjentów pediatrycznych rzadko dochodzi do progresji do późnych postaci choroby. Badania serologiczne są bezużyteczne na bardzo wczesnym etapie zakażenia, ponieważ wykrycie odpowiedzi organizmu w postaci produkcji przeciwciał wymaga czasu. Zbyt wczesne wykonanie testu diagnostycznego skutkuje dużą liczbą wyników fałszywie ujemnych, spotykanych we wczesnym stadium choroby u $70 \%$ pacjentów (11). Test potwierdzenia immunoblot to czasochłonna i kosztowna procedura, która charakteryzuje się niższą czułością w porównaniu do EIA, lecz istotnie większą swoistością. Test immunoblot może dać wynik fałszywie ujemny w pierwszych tygodniach zakażenia, co w konsekwencji może prowadzić do potrzeby wykonania drugiego oznaczenia, gdy pierwszy wynik jest wątpliwy. Immunoblot IgM jest zalecany tylko do diagnostyki wczesnego stadium choroby (do 4 tygodni) i nie powinien być stosowany w późniejszej diagnostyce. Nieprawidłowe stosowanie tej techniki u pacjentów z przedłużającymi się, niespecyficznymi objawami, może raczej ujawnić fałszywie dodatnią reakcję, niż wskazywać na prawdziwe zakażenie (14).

Zmodyfikowany dwuetapowy algorytm testowania (ang: MTTT - Modified Two-Tiered Testing) opiera się na sekwencji dwóch różnych testów immunoenzymatycznych bez użycia metody immunoblot (15). Testy serologiczne wykorzystujące jako antygen pełny lizat bakteryjny są bardzo czułe, ale mogą reagować krzyżowo z innymi epitopami. Opracowano nowy typ testu immunoenzymatycznego, w którym zastosowano rekombinowane białka lub syntetyczne peptydy unikatowe dla Borrelia burgdorferi. Testy serologiczne oparte na takich epitopach mogą być przydatne jako drugi test $\mathrm{w}$ dwuetapowym zmodyfikowanym algorytmie MTTT. Możliwe jest to dzięki minimalnej reaktywności krzyżowej nowego testu EIA z obcymi 
Low sensitivity in the early stage of Lyme disease is not the only problem that serological diagnostics poses. Another disadvantage is the persistence of specific IgM and IgG antibodies for months or years despite successful treatment (24). This results in repeated unnecessary antibiotic treatment until the serological response is no longer observed. Moreover, for children in endemic areas, previous tick bites might be responsible for positive test results. Another problem with the diagnosis of Lyme disease is the significant variability of the results in different laboratories (25). This is due to the variety of tests available on the market and different antigen panels used in them. Difficulties in interpreting test results from different laboratories result in repeated serological tests. This generates unnecessary stress in the child and increases the costs of diagnostics.

Serological tests are imperfect. Moreover, there are many misconceptions about the diagnosis of Lyme disease in children. Testing for Lyme disease in patients who do not meet the clinical criteria for the disease is not recommended and can lead to many false-positive results. This applies, for example, to the repeated ordering of serological tests in patients with autism spectrum disorder (26), although randomized studies have not proven any relationship between the occurrence of these behavioral deficits and Lyme disease (27). A patient with a positive Lyme disease test result faces multiple problems which derive from the diagnosis itself. It is particularly difficult to explain to the parents of the child the complex nature of falsepositive results and the intricacies of serological diagnosis of Lyme disease. The desire to see a negative serological test result close to zero, rather than below the manufacturer's cut-off value, is another common misunderstanding of EIA interpretation rules. Some doctors use a series of serological tests after treatment is finished to meet the expectations of parents who demand clear evidence that their child was cured.

Some data from the literature suggest that standard diagnostic procedures may leave many Lyme cases undetected. One Canadian study uses an analysis of the incidence of Lyme disease in adjacent cross-border provinces and data from observation of the disease in dogs to predict the incidence of cases in humans (28). The authors speculate that the reported incidence of Lyme disease in humans is highly underestimated. The concept, or rather the myth of the seronegativity (29) of Lyme disease, adds even more fuel to the difficultto-deny rumors about the disease.

\section{UNCONVENTIONAL TESTS}

A number of activities have been undertaken to develop completely new types of tests that would antygenami. Antygenem użytym w testach immunoenzymatycznych nowej generacji jest powierzchniowa lipoproteina E (VlsE) lub jej wybrana część, najczęściej peptyd C6 - epitop odpowiadający szóstemu, niezmiennemu regionowi (IR6) w VlsE (16). Antygeny o wysokiej ekspresji in vivo w VlsE, mogą znacząco poprawić czułość testu (17-19). Wykorzystanie w spektrum antygenowym peptydu C6 pochodzącego $\mathrm{z}$ VlsE, poprawia swoistość testu w porównaniu do lizatu pełnokomórkowego EIA $(17,20)$. Testy wykorzystujące dodatkowy antygen VlsE mogą ostatecznie zastąpić immunobloting jako test potwierdzający chorobę z Lyme. Taka strategia została oceniona na dużej grupie dzieci z objawami zapalenia stawów pozwalając prawidłowo zidentyfikować dzieci z septycznym zapaleniem stawów (21). Test został również z powodzeniem zastosowany do oceny skuteczności leczenia boreliozy (22-23), choć powtarzanie testów opartych o oznaczanie miana przeciwciał nie jest rutynowo zalecane w praktyce klinicznej.

Niska czułość we wczesnej fazie boreliozy nie jest jedynym problemem związanym z diagnostyką serologiczną. Inną wadą jest utrzymywanie się specyficznych przeciwciał IgM i IgG przez miesiące lub lata mimo skutecznego leczenia (24). Powoduje to powtórne, niepotrzebne leczenie antybiotykami w oczekiwaniu na ustąpienie odpowiedzi serologicznej. Co więcej, w przypadku dzieci zamieszkujących tereny endemiczne, pozytywny wynik testu może mieć związek z wcześniejszymi ukłuciami kleszczy. Innym problemem pojawiającym się w diagnostyce boreliozy jest znaczna zmienność wyników w zależności od wybranego laboratorium (25). Wynika to $\mathrm{z}$ różnorodności testów dostępnych na rynku i tym samym różnych paneli antygenowych wykorzystywanych przez testy opracowane przez poszczególnych producentów. Trudności $w$ interpretacji wyników badań pochodzących z różnych laboratoriów przekładają się na powtarzanie badań serologicznych generując niepotrzebny stres u dziecka oraz mnożąc koszty diagnostyki.

Niedoskonałość testów serologicznych jest faktem. Ponadto, istnieje wiele błędnych przekonań na temat diagnostyki boreliozy u dzieci. Zlecanie testów na boreliozę u pacjentów, którzy nie spełniają kryteriów klinicznych choroby nie jest zalecane i może prowadzić do wielu fałszywie dodatnich wyników. Dotyczy to przykładowo wielokrotnego zlecania testów serologicznych u pacjentów z zaburzeniami ze spektrum autyzmu (26), pomimo że w randomizowanych badaniach nie udowodniono żadnego związku występowania tych deficytów behawioralnych $\mathrm{z}$ boreliozą (27). Niezwykle trudno jest zdjąć z pacjenta „etykietę" pozytywnego wyniku badania w kierunku boreliozy. Szczególną trudność sprawia wyjaśnienie rodzicom dziecka złożonej natury fałszywie dodatnich wyników 
support the clinical diagnosis of Lyme disease. Among the many molecules that can be used in the diagnosis of Lyme disease, the chemokine CXCL13 seems to be the best known, although it is still not used in routine medical practice. CXCL13 is an important factor in the humoral immune response. Its elevated concentrations in the cerebrospinal fluid (CSF) induce the influx of B lymphocytes into the central nervous system, which results in intrathecal production of antibodies (30). The concentration of CXCL13 in the cerebrospinal fluid is elevated in neuroborreliosis in both adults and children (31-34). Interestingly, high concentration of CXCL13 may also be found in some patients suffering from other tick-borne diseases, namely tick-borne encephalitis (35). Additionally, a decrease in the concentration of CXCL 13 may indicate that the implemented antibiotic therapy is effective (36). It is also speculated that the T-cell derived cell chemokine CCL19 (37) or IFN- $\alpha$ (38) may increase the risk of post-Lyme disease syndrome (PLDS). The syndrome is characterized by the presence of recurrent, persistent pain and fatigue after treatment, and its immunological nature is not fully understood. It should be noted that PLDS is extremely rare in children. Another innovative approach that supports the diagnosis of early stage of Lyme disease is the identification of metabolic biosignatures in the serum. The body's metabolic profile changes under the influence of various factors, including infection and infectious diseases. Consequently, these changes may reflect the existence of a number of diseases and be used in their diagnosis. Studies by Bryn et al. carried out using liquid chromatography combined with mass spectrometry (LC-MS) in people with early stage Lyme disease showed changes in the metabolic pathways of some lipids related to, inter alia, inflammatory response and mitochondrial functioning (39). In the future, metabolomics may help identify biomarkers that indicate successful treatment of Lyme disease (38-40). Another new idea for the future of Lyme disease diagnostics may be to find a typical signature of gene expression in the host organism (41). In studies of the transcriptome using the next generation sequencing (NGS) method in patients with newly diagnosed Lyme disease, it was observed that the change in the expression of certain genes is unique for this disease. Out of over 1,200 genes with altered expression compared to the control group, no more than $44 \%$ coincided with the signature of changes in other diseases. Identification of the transcriptome signature in the early stage of Lyme disease may be helpful in sensitive clinical diagnosis during the so-called serological window, before the antibody response occurs (41).

Bearing in mind the imperfections of Lyme disease diagnostics based on the results of laboratory tests, the oraz zawiłości diagnostyki serologicznej boreliozy. Chęć zobaczenia wartości ujemnego wyniku badania serologicznego w pobliżu zera, a nie poniżej określonej przez producenta wartości odcięcia, jest kolejnym częstym niezrozumieniem zasad interpretacji wyniku testu EIA. Niektórzy lekarze stosują więc serię testów serologicznych po zakończonym leczeniu, aby wyjść naprzeciw oczekiwaniom rodziców, którzy chcą otrzymać jednoznaczny dowód wyleczenia swoich dzieci.

Niektóre dane z literatury sugerują, iż standardowe procedury diagnostycznie mogą pozostawiać niewykrytą dużą liczbę przypadków boreliozy. Jedno z kanadyjskich badań wykorzystuje analizę częstości występowania boreliozy w sąsiednich prowincjach transgranicznych oraz dane z obserwacji choroby u psów, aby przewidzieć częstość występowania przypadków u ludzi (28). Autorzy spekulują, iż raportowana zapadalność na boreliozę u ludzi jest mocno zaniżona. Koncepcja, a raczej mit o seronegatywności (29) boreliozy, dodaje jeszcze więcej paliwa do trudnych do rozproszenia plotek o chorobie z Lyme..

\section{NIEKONWENCJONALNE TESTY}

Podjęto szereg działań mających na celu opracowania zupełnie nowych rodzajów testów, które wspierałyby kliniczne rozpoznanie boreliozy Spośród wielu cząsteczek mogących mieć zastosowanie w diagnostyce boreliozy chemokina CXCL13, wydaje się być najlepiej poznana, choć wciąż nie jest wykorzystywana w rutynowej praktyce lekarskiej. CXCL13 jest ważnym czynnikiem humoralnej odpowiedzi immunologicznej. Jej podwyższone stężenia w płynie mózgowo rdzeniowym (PMR) wywołują napływ limfocytów B do ośrodkowego układu nerwowego, co skutkuje wewnątrzoponowym wytwarzaniem przeciwcial (30). Stężenie CXCL13 w płynie mózgowo rdzeniowym jest podwyższone w neuroboreliozie zarówno u dorosłych, jak i u dzieci (31-34). Co ciekawe, stężenie CXCL13 może być również wysokie u niektórych pacjentów cierpiących na inne choroby odkleszczowe, a mianowicie kleszczowe zapalenie mózgu (35). Dodatkowo spadek jej stężenia może świadczyć o skuteczności wdrożonej antybiotykoterapii (36). Ponadto spekulowano rozważano również, że inna chemokina komórkowa CCL19 pochodząca z limfocytów T (37) czy też IFN alfa (38) mogą być czynnikami ryzyka rozwoju zespołu poboreliozowego. Zespół ten charakteryzuje obecność nawracającego, uporczywego bólu i zmęczenia po leczeniu, a jego immunologiczny charakter nie jest do końca poznany. Należy zauważyć, iż zespół poboreliozowy niezwykle rzadko występuje u dzieci. Innym nowatorskim podejściem wspomagającym diagnostykę wczesnego stadium choroby w Lyme jest identyfikacja biosygnatur metabolicznych w surowicy pacjen- 
idea of diagnosing the disease in children based on the clinical symptoms was put forward (42).

\section{DIAGNOSIS BASED ON CLINICAL SYMPTOMS}

Erythema migrans is an expanding rash often seen in the early stage of Lyme disease and the most common symptom of the disease in children. It is widely believed that erythema migrans, due to its key features such as location, size and appearance, enables the diagnosis of Lyme disease without additional laboratory tests. Unfortunately, this characteristic skin lesion does not occur in every patient, and even if it does, it often goes completely unnoticed. In children, erythema migrans is even more difficult to observe than in adults. In shorter children tick bites are more common on the head and neck than on the limbs (4344). Nymphs and even adult ticks can be barely visible on the scalp, so a tick bite in this area may not be recognized for a long time. Moreover, sometimes the skin lesion's shape does not resemble the typical "bull's eye". Thus, it makes it more difficult to diagnose the disease. The diagnosis of Lyme disease requires for the erythema's diameter to be is at least $5 \mathrm{~cm}$ (45), although this minimum size should be regarded only as a clue. Erythema migrans also requires differentiation from a local allergic reaction to a tick bite, which appears immediately after the bite, does not increase in diameter and may be accompanied by itching. Moreover, a significant percentage of children have multiple erythema migrans, defined as multiple skin lesions appearing outside the tick bite site (46). These patients need accurate differential diagnosis. Multiple erythema migrans requires careful differentiation from other erythematous changes found in children, such as hives, erythema multiforme or serum sickness.

\section{SUMMARY}

We need a breakthrough laboratory technique in the diagnosis of Lyme disease that will support clinicians in making treatment decisions. While significant progress has been made recently, there is still room for further development in this area. A sensitive diagnostic test that confirms only an active infection is still not available in clinical practice and remains every clinician's dream. In doubtful cases, the solution seems to be to combine the various techniques available, for example a new serological technique with advanced direct testing. Individualized diagnostics may be required for children with different symptoms of Lyme disease. It would be very difficult to develop a universal diagnostic protocol for every child with Lyme disease. tów. Profil metaboliczny organizmu zmienia się pod wpływem różnych czynników, w tym infekcji i chorób zakaźnych. Co za tym idzie zmiany w nim mogą odzwierciedlać stan choroby i być wykorzystywane do diagnostyki różnych chorób. Badania Bryna i współautorów przeprowadzone metodą chromatografii cieczowej połączonej ze spektrometrią mas (LC-MS) u osób $\mathrm{z}$ wczesną fazą boreliozy wykazały zmiany w szlakach metabolicznych niektórych lipidów związanych między innymi z odpowiedzią zapalną i funkcjonowaniem mitochondriów (39). W przyszłości metabolomika może pomóc zidentyfikować biomarkery wskazujące na skuteczne leczenie choroby z Lyme (38-40). Kolejnym nowym pomysłem na przyszłość diagnostyki boreliozy może być znalezienie typowej sygnatury ekspresji genów w organizmie gospodarza (41). W badaniach transkryptomu metodą sekwencjonowania nowej generacji (next generation sequencing - NGS) pacjentów ze świeżo rozpoznaną boreliozą zauważono, że zmiana ekspresji niektórych genów jest unikatowa dla tej jednostki chorobowej. Spośród ponad 1200 genów o ekspresji zmienionej względem grupy kontrolnej, nie więcej niż $44 \%$ pokrywało się z sygnaturą zmian w innych jednostkach chorobowych. Identyfikacja trwałej sygnatury transkryptomu we wczesnej fazie boreliozy może stać się w przyszłości pomocna w czułej diagnostyce klinicznej, w , oknie serologicznym” jeszcze przed pojawieniem się odpowiedzi w postaci produkcji przeciwciał (41).

Mając na uwadze niedoskonałości diagnostyki choroby z Lyme opartej na wynikach badań laboratoryjnych wysunięto pomysł rozpoznawania choroby u dzieci bazując na objawach klinicznych choroby (42).

\section{DIAGNOZA OPARTA NA OBECNOŚCI CHARAKTERYSTYCZNYCH OBJAWÓW KLINICZNYCH}

Rumień wędrujący to stopniowo powiększająca się zmiana skórna, występująca we wczesnym stadium boreliozy, najczęstszy objaw choroby u dzieci. Powszechnie uważa się, iż rumień wędrujący ze względu na swoje kluczowe cechy takie jak lokalizacja, rozmiar i wygląd, pozwala na rozpoznania choroby z Lyme bez konieczności wykonywania dodatkowych badań laboratoryjnych. Niestety nie u każdego pacjenta na skórze pojawia się ta charakterystyczna zmiana skórna, niejednokrotnie też pozostaje kompletnie niezauważona. U dzieci zaobserwowanie rumienia wędrującego może być nawet trudniejsze, niż u dorosłych. U tych dzieci, które są niższego wzrostu, ukłucia kleszczy spotyka się częściej w okolicy głowy i szyi niż na kończynach (43-44). Nimfy, a nawet dorosłe kleszcze mogą być ledwo widoczne w skórze owłosionej głowy, dlatego ukłucie kleszcza w tej okolicy może być długo nieroz- 
Due to the lack of uniform diagnostic protocols, which makes it difficult to provide appropriate therapeutic recommendations, the prevention of Borrelia infections is important. As immunization is currently unavailable, the only way to prevent Lyme disease is to avoid tick bites. Thus, avoiding risk areas, using tick repellents and wearing appropriate clothing is recommended. In addition, early tick removal is of great importance, because it prevents the transmission of infection from an infected tick. If a child is exposed to Borrelia, the history of recent antibiotic therapy should be carefully examined. Many children are treated for respiratory infections with beta-lactam or macrolide antibiotics several times a year. Thus it possible that no additional treatment is required after the diagnosis of Lyme disease, because the patient already receives medication for another infection. Although there are numerous problems with the diagnostics of Lyme disease in children, there is also good news: children respond well to early treatment, and therefore longterm effects of the disease or the development of its chronic forms are unlikely in properly treated patients in this age group.

\section{REFERENCES}

1. Steere AC, Malawista SE, Snydman DR, et al. Lyme arthritis: an epidemic of oligoarticular arthritis in children and adults in three connecticut communities. Arthritis Rheum. 1977;20(1):7-17. doi:10.1002/art.1780200102

2. BurgdorferW.How the discoveryofBorreliaburgdorferi came about. Clinics in Dermatology. 1993;11(3):335338. doi:10.1016/0738-081X(93)90087-S

3. Sapi E, Pabbati N, Datar A, Davies EM, Rattelle A, Kuo BA. Improved culture conditions for the growth and detection of Borrelia from human serum. Int J Med Sci. 2013;10(4):362-376. doi:10.7150/ijms.5698

4. Strle F, Nelson JA, Ruzic-Sabljic E, et al. European Lyme borreliosis: 231 culture-confirmed cases involving patients with erythema migrans. Clin Infect Dis. 1996;23(1):61-65. doi:10.1093/ clinids/23.1.61

5. Cerar T, Ruzić-Sabljić E, Glinsek U, Zore A, Strle F. Comparison of PCR methods and culture for the detection of Borrelia spp in patients with erythema migrans. Clin Microbiol Infect. 2008;14(7):653658. doi:10.1111/j.1469-0691.2008.02013.x

6. Tee S-I, Martínez-Escanamé M, Zuriel D, et al. Acrodermatitis chronica atrophicans with pseudolymphomatous infiltrates. Am J Dermatopathol. 2013;35(3):338-342. doi:10.1097/ DAD.0b013e31826b7487

7. Eshoo MW, Crowder CC, Rebman AW, et al. Direct molecular detection and genotyping of Borrelia poznane. Ponadto niekiedy zmiana skórna nie ma typowego wyglądu o kształcie przypominającym „tarczę strzelniczą" i tym samym rozpoznanie choroby może nie być tak oczywiste. Średnica rumienia pozwalająca na rozpoznanie boreliozy wynosi co najmniej $5 \mathrm{~cm}$ (45) choć ten minimalny rozmiar należy traktować jednie orientacyjnie. Rumień wędrujący wymaga również różnicowania $\mathrm{z}$ miejscową reakcją alergiczną na ukąszenie kleszcza, która pojawia się zaraz po ukłuciu, nie zwiększa swojej średnicy oraz może towarzyszyć jej świąd. Ponadto u znacznego odsetka dzieci występuje rumień wędrujący mnogi definiowany jako liczne zmiany skórne pojawiające się poza pierwotnym miejscem ukłucia kleszcza (46). U tych pacjentów konieczna jest dokładna diagnostyka różnicowa. Mnogi rumień wędrujący wymaga wnikliwego różnicowania $\mathrm{z}$ innymi zmianami rumieniowymi spotykanymi u dzieci takimi jak pokrzywka, rumień wielopostaciowy lub reakcja typu choroby posurowiczej.

\section{PODSUMOWANIE}

W diagnostyce choroby z Lyme oczekuje się na przełomową technikę laboratoryjną, która wesprze klinicystów w rozpoznawaniu choroby i ich decyzjach dotyczących leczenia. Choć ostatnio poczyniono znaczące postępy, wciąż jest miejsce na dalszy rozwój w tym obszarze. Czuły test diagnostyczny, który potwierdza jedynie aktywną infekcję, wciąż nie jest dostępny w praktyce klinicznej pozostaje w „sferze marzeń" każdego klinicysty. W wątpliwych przypadkach rozwiązaniem wydaje się być łączenie różnych dostępnych technik, jak choćby nowej techniki serologicznej z zaawansowanymi testami bezpośrednimi. Być może konieczne będzie stosowanie diagnostyki zindywidualizowanej dla dzieci z różnymi objawami choroby z Lyme. Opracowanie uniwersalnego protokołu diagnostycznego dla każdego dziecka z chorobą z Lyme może być trudne do osiągniecia.

Brak jednolitych protokołów diagnostycznych utrudniających wydanie właściwych zaleceń terapeutycznych sprawia, że istotna pozostaje profilaktyka zakażeń krętkami Borrelia. Ponieważ obecnie nie jest dostępne szczepienie ochronne, jedynym sposobem zapobiegania chorobie z Lyme jest unikanie ukąszeń przez kleszcze. Oznacza to omijanie obszarów zagrożonych, używanie środków odstraszających pajęczaki i stosowanie odpowiedniej odzieży. Nie można pominąć roli, jaką przypisuje się wczesnemu usuwaniu kleszczy, co zapobiega przeniesieniu zakażenia nawet w przypadku ukłucia przez zainfekowanego krętkami kleszcza. W przypadku narażenia dziecka na zakażenie Borrelia należy dokładnie zbadać wywiad odnośnie niedawno stosowanej antybiotykoterapii. Duża część dzieci kilka razy w roku jest leczona 
burgdorferi from whole blood of patients with early Lyme disease. PLoS ONE. 2012;7(5):e36825. doi:10.1371/journal.pone.0036825

8. Nocton JJ, Bloom BJ, Rutledge BJ, et al. Detection of Borrelia burgdorferi DNA by polymerase chain reaction in cerebrospinal fluid in Lyme neuroborreliosis. J Infect Dis. 1996;174(3):623627. doi:10.1093/infdis/174.3.623

9. Liveris D, Schwartz I, McKenna D, et al. Comparison of five diagnostic modalities for direct detection of Borrelia burgdorferi in patients with early Lyme disease. Diagn Microbiol Infect Dis 2012;73(3):243-245. doi:10.1016/j. diagmicrobio.2012.03.026

10. Branda JA, Lemieux JE, Blair L, et al. Detection of Borrelia burgdorferi Cell-free DNA in Human Plasma Samples for Improved Diagnosis of Early Lyme Borreliosis. Clin Infect Dis Published online June 25, 2020. doi:10.1093/cid/ciaa858

11. Steere AC, McHugh G, Damle N, Sikand VK. Prospective study of serologic tests for lyme disease. Clin Infect Dis. 2008;47(2):188-195. doi:10.1086/589242

12. Stricker RB, Johnson L. Let's tackle the testing. BMJ. 2007;335(7628):1008. doi:10.1136/ bmj.39394.676227.BE

13. Cook MJ, Puri BK. Commercial test kits for detection of Lyme borreliosis: a meta-analysis of test accuracy. Int J Gen Med. 2016;9:427-440. doi:10.2147/IJGM.S122313

14. Halperin JJ, Baker P, Wormser GP. Common misconceptions about Lyme disease. Am J Med 2013;126(3):264.e1-7.doi:10.1016/j.amjmed.2012.10.008

15. Strobino B, Steinhagen K, Meyer W, et al A Community Study of Borrelia burgdorferi Antibodies among Individuals with Prior Lyme Disease in Endemic Areas. Healthcare (Basel). 2018;6(2). doi:10.3390/healthcare6020069

16. Gomes-Solecki MJC, Meirelles L, Glass J, Dattwyler RJ. Epitope length, genospecies dependency, and serum panel effect in the IR6 enzyme-linked immunosorbent assay for detection of antibodies to Borrelia burgdorferi. Clin Vaccine Immunol 2007;14(7):875-879. doi:10.1128/ CVI.00122-07

17. Branda JA, Linskey K, Kim YA, Steere AC, Ferraro MJ. Two-tiered antibody testing for Lyme disease with use of 2 enzyme immunoassays, a whole-cell sonicate enzyme immunoassay followed by a VlsE C6 peptide enzyme immunoassay. Clin Infect Dis. 2011;53(6):541-547. doi:10.1093/cid/cir464

18. Branda JA, Aguero-Rosenfeld ME, Ferraro MJ, Johnson BJB, Wormser GP, Steere AC. 2-tiered antibody testing for early and late Lyme disease using only an immunoglobulin $G$ blot with the addition of a VlsE band as the second-tier test. Clin Infect Dis. 2010;50(1):20-26. doi:10.1086/648674 antybiotykami beta-laktamowymi lub makrolidowymi z powodu zakażeń dróg oddechowych. Może się zdarzyć, że w momencie rozpoznania boreliozy nie będzie potrzebne dalsze leczenie, ponieważ zostało ono już zrealizowane właśnie w ramach leczenia innej infekcji. Chociaż napotykamy tak wiele problemów diagnostycznych boreliozy u dzieci, jest też dobra wiadomość: dzieci dobrze reagują na wcześnie zastosowane leczenie i tym samym wystąpienie odległych następstw choroby lub rozwój postaci przewlekłych, co u prawidłowo leczonych pacjentów jest mało prawdopodobne w tej grupie wiekowej.

19. Bacon RM, Biggerstaff BJ, Schriefer ME, et al. Serodiagnosis of Lyme disease by kinetic enzymelinked immunosorbent assay using recombinant VlsE1 or peptide antigens of Borrelia burgdorferi compared with 2-tiered testing using wholecell lysates. J Infect Dis. 2003;187(8):1187-1199. doi:10.1086/374395

20. Wormser GP, Schriefer M, Aguero-Rosenfeld ME, et al. Single-tier testing with the C6 peptide ELISA kit compared with two-tier testing for Lyme disease. Diagn Microbiol Infect Dis. 2013;75(1):915. doi:10.1016/j.diagmicrobio.2012.09.003

21. Nigrovic LE, Bennett JE, Balamuth $F$, et al. Diagnostic Performance of C6 Enzyme Immunoassay for Lyme Arthritis. Pediatrics. 2020;145(1). doi:10.1542/peds.2019-0593

22. Philipp MT, Bowers LC, Fawcett PT, et al. Antibody response to IR6, a conserved immunodominant region of the VlsE lipoprotein, wanes rapidly after antibiotic treatment of Borrelia burgdorferi infection in experimental animals and in humans. J Infect Dis. 2001;184(7):870-878. doi: $10.1086 / 323392$

23. Philipp MT, Wormser GP, Marques AR, et al. A decline in $\mathrm{C} 6$ antibody titer occurs in successfully treated patients with culture-confirmed early localized or early disseminated Lyme Borreliosis. Clin Diagn Lab Immunol. 2005;12(9):1069-1074. doi:10.1128/CDLI.12.9.1069-1074.2005

24. Feder HM, Gerber MA, Luger SW, Ryan RW. Persistence of serum antibodies to Borrelia burgdorferi in patients treated for Lyme disease. Clin Infect Dis. 1992;15(5):788-793. doi:10.1093/ clind/15.5.788

25. Fallon BA, Pavlicova M, Coffino SW, Brenner C. A comparison of lyme disease serologic test results from 4 laboratories in patients with persistent symptoms after antibiotic treatment. Clin Infect Dis. 2014;59(12):1705-1710. doi:10.1093/cid/ciu703

26. Bransfield RC, Wulfman JS, Harvey WT, Usman AI. The association between tick-borne infections, Lyme borreliosis and autism spectrum 
disorders. Med Hypotheses. 2008;70(5):967-974. doi:10.1016/j.mehy.2007.09.006

27. Ajamian M, Kosofsky BE, Wormser GP, Rajadhyaksha AM, Alaedini A. Serologic markers of Lyme disease in children with autism. JAMA. 2013;309(17):1771-1773. doi:10.1001/jama.2013.618

28. Lloyd VK, Hawkins RG. Under-Detection of Lyme Disease in Canada. Healthcare (Basel). 2018;6(4). doi:10.3390/healthcare6040125

29. Dattwyler RJ, Volkman DJ, Luft BJ, Halperin JJ, Thomas J, Golightly MG. Seronegative Lyme disease. Dissociation of specific T- and B-lymphocyte responses to Borrelia burgdorferi. N Engl J Med. 1988;319(22):1441-1446. doi:10.1056/ NEJM198812013192203

30. Irani DN. Regulated Production of CXCL13 within the Central Nervous System. J Clin Cell Immunol. 2016;7(5). doi:10.4172/2155-9899.1000460

31. Markowicz M, Schötta A-M, Kundi M, et al. CXCL13 concentrations in cerebrospinal fluid of patients with Lyme neuroborreliosis and other neurological disorders determined by Luminex and ELISA. Ticks Tick Borne Dis. 2018;9(5):11371142. doi:10.1016/j.ttbdis.2018.04.008

32. Pietikäinen A, Oksi J, Hytönen J. Point-of-care testing for CXCL13 in Lyme neuroborreliosis. Diagn Microbiol Infect Dis. 2018;91(3):226-228. doi:10.1016/j.diagmicrobio.2018.02.013

33. Remy MM, Schöbi N, Kottanattu L, Pfister S, Duppenthaler A, Suter-Riniker F. Cerebrospinal fluid CXCL13 as a diagnostic marker of neuroborreliosis in children: a retrospective casecontrol study. J Neuroinflammation. 2017;14(1):173. doi:10.1186/s12974-017-0948-9

34. Barstad B, Tveitnes D, Dalen I, et al. The B-lymphocyte chemokine CXCL13 in the cerebrospinal fluid of children with Lyme neuroborreliosis: associations with clinical and laboratory variables. Infect Dis (Lond). 2019;51(1112):856-863. doi:10.1080/23744235.2019.1671988

35. Toczylowski K, Grygorczuk S, Osada J, et al. Evaluation of cerebrospinal fluid CXCL13 concentrations and lymphocyte subsets in tickborne encephalitis. Int J Infect Dis. 2020;93:40-47. doi:10.1016/j.ijid.2020.01.023

36. Yang J, Han X, Liu A, et al. Chemokine CXC Ligand 13 in Cerebrospinal Fluid Can Be Used as an Early Diagnostic Biomarker for Lyme Neuroborreliosis: A Meta-Analysis. J Interferon Cytokine Res. 2017;37(10):433-439. doi:10.1089/ jir.2016.0101

37. Aucott JN, Soloski MJ, Rebman AW, et al. CCL19 as a Chemokine Risk Factor for Posttreatment Lyme Disease Syndrome: a Prospective Clinical Cohort Study. Clin Vaccine Immunol. 2016;23(9):757-766. doi:10.1128/CVI.00071-16
38. Jacek E, Fallon BA, Chandra A, Crow MK, Wormser GP, Alaedini A. Increased IFN $\alpha$ activity and differential antibody response in patients with a history of Lyme disease and persistent cognitive deficits. J Neuroimmunol. 2013;255(1-2):85-91. doi:10.1016/j.jneuroim.2012.10.011

39. Fitzgerald BL, Molins CR, Islam MN, et al. Host Metabolic Response in Early Lyme Disease. J Proteome Res. 2020;19(2):610-623. doi:10.1021/ acs.jproteome.9b00470

40. Molins CR, Ashton LV, Wormser GP, et al. Development of a metabolic biosignature for detection of early Lyme disease. Clin Infect Dis. 2015;60(12):1767-1775. doi:10.1093/cid/civ185

41. Bouquet J, Soloski MJ, Swei A, et al. Longitudinal Transcriptome Analysis Reveals a Sustained Differential Gene Expression Signature in Patients Treated for Acute Lyme Disease. mBio. 2016;7(1):e00100-00116. doi:10.1128/mBio.00100-16

42. Lyme Disease 135, 136 |Red Book ${ }^{\circledR} 2018$ |Red Book Online | AAP Point-of-Care-Solutions. Published September 6, 2020. Accessed September 6, 2020. https://redbook.solutions.aap.org/chapter.aspx? sectionId $=189640125 \&$ bookId $=2205$ \& resultClick $=1$

43. Cull B, Pietzsch ME, Gillingham EL, McGinley L, Medlock JM, Hansford KM. Seasonality and anatomical location of human tick bites in the United Kingdom. Zoonoses Public Health. 2020;67(2):112-121. doi:10.1111/zph.12659

44. Hügli D, Moret J, Rais O, et al. Tick bites in a Lyme borreliosis highly endemic area in Switzerland. Int J Med Microbiol. 2009;299(2):155-160. doi:10.1016/j.ijmm.2008.06.001

45. Vig DK, Wolgemuth CW. Spatiotemporal Evolution of Erythema Migrans, the Hallmark Rash of Lyme Disease. Biophys J. 2014;106(3):763768. doi:10.1016/j.bpj.2013.12.017

46. Glatz M, Resinger A, Semmelweis K, AmbrosRudolph CM, Müllegger RR. Clinical spectrum of skin manifestations of Lyme borreliosis in 204 children in Austria. Acta Derm Venereol. 2015;95(5):565-571. doi:10.2340/00015555-2000

Received:30.11.2020 r.

Accepted for publication:14.12.2020 r.

Otrzymano: 30.11.2020 r.

Zaakceptowano do publikacji: $14.12 .2020 \mathrm{r}$.

\section{Address for correspondence: Adres do korespondencji:}

Dr hab. n. med. Artur Sulik

Klinika Obserwacyjno-Zakaźna Dzieci, Uniwersytet Medyczny w Białymstoku,

ul. Waszyngtona 17, 15-274 Białystok

telefon: 857450685

e-mail: artur.sulik@umb.edu.pl 